\title{
Abortion for fetal anomaly: how to speak about a difficult topic
}

\author{
Indicação de aborto por anomalia fetal: como \\ abordar um assunto difícil
}

\author{
Aborto por anomalía fetal: cómo hablar sobre un \\ tema difícil
}

Ilana Löwy 1

doi: 10.1590/0102-311X00188618

\section{Abortion in context}

Abortion is a highly polarizing topic. It is presented by its supporters as woman's right to decide whether she wished to be a mother in a specific moment of her life, and by its opponents as killing of a future (and for some an already existing) human being. The latter view is often presented as absolute and extemporal. Yet, in practice, attitudes towards state's control over the fate of embryos and fetuses are always situated. In France, conservative Catholics are mainly concerned by a child's right to have a biological mother and father. They strongly oppose the right of homosexual - but not heterosexual - couples to employ assisted reproduction technologies, artificial insemination included, but seldom publicly contest the decriminalization of abortion. In Poland, the Catholic Church vigorously rejects the legalization of abortion, but also in vitro fertilization - including for heterosexual, married couples - because it involves a destruction of human embryos. In Brazil, conservative Christians rarely opose in vitro fertilization or the use of assisted reproduction technologies by homosexual women, and focuses on keeping abortion illegal.

Attitudes towards embryos and fetuses also evolved with time. The equation of a fetus with an already existing child is relatively new. Scholars pointed out to the role of obstetrical ultrasound and the proliferation of fetal images that show a small, baby like entity, in strengthening view of a fetus as "my child" 1,2. However, since miscarriages are frequent, the knowledge that a fetus looks like a miniature baby did not originate with ultrasound images. In early and mid 20th Century it was propagated by popular books about pregnancy, a trend that culminated in Lennart Nilsson's 1965 famous photo essay, Drama of Life Before Birth. This essay illustrated in fact "death before birth": it presented photographs of miscarried and legally aborted fetuses 3 . In the 1930s and 1940s, some women agreed to give their miscarried fetuses for research. Scientific films which showed the stimulation of these - dying-fetuses with soft hairs to elicit their reflex movements were hailed in popular magazines as an important contribution to the study of human development. Entities that looked like tiny babies were unproblematically perceived as experimental material 4 . Attitudes to premature babies kept in incubators and displayed in the early 20th century in highly lucrative "baby shows" were even more striking. Until the 1920s, parents who "loaned" their premature babies to the organizers of such shows often did not manifest future interest in their child: if the baby survived (this happened in about one
1 Universidade do Estado do Rio de Janeiro, Rio de Janeiro, Brasil.

Correspondence I. Löwy Universidade do Estado do Rio de Janeiro. Rua São Francisco Xavier 524 , bloco D, 7o andar, Rio de Janeiro, RJ 20550-013, Brasil. ilana.lowy@cnrs.fr 
third of the cases) the "loan" was transformed into a "gift" 5. In the early 20th Century even a living and breathing baby-like entity was not always perceived as a child.

In the 1960s and 1970s, at the high point of debates on the liberalization of abortion in Western Europe and North America, Catholic and Protestant theologians expressed a wide range of opinions on this topic. Some argued then that the transformation of a fetus into a child during the pregnancy is a gradual biological and social process, and that in some circumstances an abortion can be seen as a lesser evil 6 . The rigidification of religious positions on this question in the 1980s and 90s was partly the consequence of "abortion wars". especially in the USA, and partly the outcome of a new alliance between opponents of abortion and disability rights activists.

\section{Disability rights and prenatal diagnosis}

Brazilian law allows interruption of pregnancy for anencephaly, an uniformly lethal malformation, but not for fetal impairment which does not always lead to death of the newborn child. In the majority of the countries which legalized abortion (but not in USA) the law specifies conditions that allow termination of pregnancy for a severe fetal anomaly. In the 1960s and 1970s, an abortion for "social reasons" (the refusal of a child) was often perceived as less legitimate than an abortion for "medical reasons" (the refusal of thi - impaired - child). The latter was often justified by the pregnant woman's wish to spare her future child difficulties of life with a severe impairment 7,8. Activists of the religious anti-abortion movement, especially in the US, advanced, however, the opposite argument: a refusal to give birth to a disabled child is worse than a mere refusal of pregnancy, because in that case pregnant women classify human beings along a scale of perfection and decide who is not entitled to live 7 . In the 1980s and 1990s this argument was adopted by disability rights activists who argued that termination of pregnancy for a fetal malformation is an implicit statement that life with disability is worthless 9. This argument, named "expressivist objection", was coupled by some disability activists with a critique of an utilitarian, neo-liberal society in which only "productive" individuals are seen as entitled to full human rights, while those unable to contribute to the collective well-being are viewed as a "burden". Disability, these activists proposed, is a social and not medical condition, and a just society should provide an environment which allow all its members, able-bodied or not, to live happy and fulfilling lives.

The "expressivist objection", promoted jointly by anti-abortion and disability activists, is an emotionally powerful argument. It is also a problematic one. It lumps together very different conditions and degrees of impairment, focuses on "healthy disabled" who do not need constant medical attention, extrapolates from "exemplary disabilities", frequently compatible with autonomous life (limited mobility, deafness, impaired sight, short size) to all the others. It also carefully avoids (beside the vague statement that the "society" should provide for all its disabled members) the thorny question of care for severely disabled children/adults, and mothers' central role in providing such - unpaid - care, even in relatively affluent societies. Opponents of abortion for a fetal impairment often present it as reflecting families' growing unwillingness to accept the birth of an "imperfect" child. Yet, the woman who want a "perfect child" and is willing to terminate a pregnancy for a minor fetal anomaly seems to exists mainly in bioethicists' theoretical debates. Empirical studies indicate that women who ask a permission to terminate a pregnancy for a fetal indication nearly always have very serious arguments to support their plea.

Disability activists' critique of abortion for fetal anomaly strongly affected debates on this topic. Today, the accepted belief is that people with disabilities perceive an abortion for a non-lethal fetal impairment as an eugenic tentative to exterminate individuals like them. This view conflates the opinion of people with disabilities/parents of disabled children with the position of organizations that claim to speak on their behalf. However, organizational viewpoints may be unrepresentative of what is a wide range of individual experiences, perceptions and viewpoints. Individuals with a hereditary condition may have diverse opinions about the prevention of its transmission. Some are hurt by selective abortion of fetuses with the same condition they have, while others held the opposite view, and are willing to go to considerable lengths to spare their future children the difficulties they had faced. A diversity of views about life with a disability may be easier to express in the absence of 
visible and active patients' associations that frequently propagate - often through the voice of a small number of devoted and charismatic leaders - a strong opinion against all forms of "eugenic abortion". Views promoted by disability rights organizations make the expression of dissenting opinions more difficult 10. They also strengthen a negative image of the "selfish" woman who refuses to give birth to a severely disabled child.

\section{Zika and abortion: how the debate has shifted}

The short movie, Zika The Film, produced by the Debora Diniz and her colleagues from the Anis Bioethics Institute starts with an image of pregnant women in the waiting room of ultrasound service in Campina Grande (Paraíba State), accompanied by a comment made by Dr. Adriana Melo, a pioneer of studies of congenital Zika syndrome: "the level of emotional stress of these women is incredible. It seems that they are facing death row, or some kind of concentration camp, and here is where they'll receive their sentence". Melo's description resonates with the argument advanced by Anis's activists. In April 2016 the Anis Institute filed a petition to the Brazilian supreme court claiming that pregnant women who know that they contracted Zika should be allowed to terminate the pregnancy because the uncertainty about the future child's fate induces an intolerable mental suffering.

Anis's petition was made at a high point of fears generated by the "epidemics of microcephaly" in Northeastern Brazil. The view of Zika at the origin of this petition was later complicated by two elements: an observation that in the majority of the cases an infection with Zika virus is asymptomatic and difficult to diagnose, and a parallel observation that only in a minority of cases such an infection produces severe fetal anomalies. Facing an undefined risk of an unknown magnitude one could propose to women in epidemic areas a careful monitoring of pregnancy and, if such monitoring detects major fetal anomalies, a possibility to choose to terminate the pregnancy. In such a configuration, women could elect abortion not only because of the mental anguish produced by uncertainty, but also when confronted with concrete evidence of fetal impairment. Reacting to an article published in American Journal of Public Health that mentioned the second possibility, Debora Diniz explained however, that, "I am leading a group who will demand that the Brazilian Supreme Court protect women's fundamental rights violated by the epidemic. The right to terminate a pregnancy will be included in our demands, but the ethical reasons for our petition are largely different from the authors' arguments: women have the right to decide to be freed of psychological torture imposed by the epidemic. It is not the fetus's future impairments or the 'extreme negative consequences for the families affected' that moves our demand" 11 (p. e9).

Another Brazilian scholar, Pablo Valente 12 (p. 1378), similarly argued that allowing abortion for malformations produced by Zika virus is highly problematic, because, "legal instruments to allow abortion only in cases of fetal malformations may promote stigmatization of people with disabilities". Legal instruments that allow abortion only in cases of fetal malformations are, however, a fiction. No country allows an abortion exclusively in cases of fetal anomaly. Some, like the USA, allow abortion without providing any motive, usually up to the limit of fetal viability, while others, like the majority of Western European countries, allow a no-conditions abortion only until a specific time in pregnancy. Beyond this time a woman who wishes to terminate a pregnancy for a fetal indication has to obtain a permission of an ethics committee. Such a permission is, however, usually granted, because in nearly all the cases demands of an abortion for fetal indication are motivated by severe and incurable fetal problems 13 .

Debora Diniz starts her pioneering book on Zika epidemics in Brazil rich in moving testimonies of women affected by this epidemics, with the story of an Italian woman, Sophia Tezza 14. Tezza contracted Zika early in pregnancy, during her stay in Natal (Rio Grande do Norte State). She then returned to Italy, and, in the third trimester of pregnancy had learned that the fetus displays a severe brain anomaly. Tezza told Diniz that she then went to Ljubljana, Slovenia, to a well-known center of tropical medicine. While in Ljubljana, her child died in the womb; the local doctors isolated Zika virus from the stillborn child's body. An article about this case, one of the first publications about isolation of Zika virus from an neurologically impaired fetus, tells a different story - the one of a woman who asked, and obtained, a permission of the ethics committee of Ljubljana hospital to terminate her pregnancy for a fetal indication. Ljubljana physicians confirmed that Tezza came to Slovenia to 
seek an abortion because in Italy it is not possible to have an abortion after the limit of fetal viability (there is no center of tropical medicine in Ljubljana). Italian journals who reported this case similarly explained that an Italian woman had to travel to Slovenia for a late abortion for Zika-induced anomalies; some added that it is a shame that she was unable to terminate her pregnancy in Italy.

A woman who went through an intensly traumatic experience found solace in the conviction that she lived a drama entirely independent of her will. This, highly understandable belief, regards only her. Alas, the telling her version of the story in a best-selling book may be interpreted as a statement that a woman whose child died in the womb following an infection with Zika virus is fully entitled to our compassion - and, implicitly, that a woman who elected an abortion after learning about a severe but non-lethal fetal anomaly is not. In the meantime, the frequency of infections with Zika virus in Brazil diminished greatly, and public attention had shifted to the fate of babies with congenital Zika syndrome and their mothers. The new identification of Zika with the - very important - struggle for rights of disabled children and their families, and the - somewhat more problematic - diffusion of idealized images of "special mothers of special children", chosen by God knowing that they would be able to look after a severely impaired child (e.g., Guiland 15), may lead to further condemnation of women who elect not to become such "special mothers"

\section{Abortion for a fetal impairment: an insoluble dilemma?}

Advocates of decriminalization of abortion frequently employ the language of human rights: a pregnant woman has the right to choose whether she want to have a child. This argument is seen as inacceptable by opponents of abortion who claim that the unborn child's right to life is much stronger that a woman's right to decide not to be a mother: for example, she can give the child for adoption. A decision to give a child for adoption often produces an intense suffering that may last all the woman's life, but for unconditional opponents of abortion this is not a sufficient reason to legitimate an act which, for them, is equivalent to a murder. Debates focused on rights can thus lead to an impasse grounded in the deep ambivalence about the status of fetuses and pregnant women. A pregnant woman are the only exception to the democratic principle of sanctity of individual rights. She is not in/dividual, since in some circumstances she may be perceived as divisible in legal terms 16 . Abortion for a fetal anomaly, often performed in second, and sometimes even the third trimester of pregnancy, accentuates the potential tension between woman's rights and those of her future child.

It may be very difficult to reach a consensus over a definition of the status of a fetus. It may be equally difficult to define what amount of "woman's intolerable suffering" is sufficient to justify an abortion for apprehended or confirmed fetal impairement, or how such suffering should be weighed against the potential suffering of disabled people who claim to be hurt by selective abortions. This does not mean, however, that termination of pregnancy following a diagnosis of a fetal anomaly is condemned for remaining forever in a legal limbo. An US jurist, Katie Watson, argues that while it is very difficult to ground abortion rights in an - today quasi unattainable - agreement on the status of the fetus, it is possible to ground such rights in a consensus about a radical absence of consensus, that is, the view that one of the costs - and pleasures - of a pluralist society is the acceptance of the principle of living with radical disagreements on some questions 17 . It is possible to be strongly opposed to abortion on religious or moral ground, and still agree that the state have no right to force a woman to continue an unwanted pregnancy, that is, remove the question of abortion, including for a fetal indication, from the legal sphere to the one of personal beliefs and individual conscience. 


\section{Additional information}

ORCID: Ilana Löwy (0000-0001-6963-0578)

\section{References}

1. Duden B. Disembodying women: perspectives on pregnancy and the unborn. Cambridge: Harvard University Press; 1993.

2. Sanger C. About abortion: terminating pregnancy in twenty-first-century America. Cambridge: Harvard University Press; 2017.

3. Jülich $\mathrm{S}$. The making of a best-selling book on reproduction: a child is born. Bull Hist Med 2015; 89:491-525.

4. Wilson E. Ex utero: live human fetal research and the films of davenport hooker. Bull Hist Med 2014; 88:132-60.

5. Silverman W. Incubator-baby side shows. Pediatrics 1979; 64:127-41.

6. Herzog D. Abortion, Christianity, disability: Western Europe, 1960s-1970s. In: Hekma G, Giami A, editors. Sexual revolution. London: Palgrave McMillan; 2014. p. 249-63. (Gender and Sexualities in History Series).

7. Luker K. Abortion and the politics of motherhood. Oakland: University of California Press; 1985.

8. Gammeltoft T. Haunting images a cultural account of selective reproduction in Vietnam. Berkeley: California University Press; 2014.

9. Asch A. Prenatal diagnosis and selective abortion: a challenge to practice and policy. Am J Public Health 1999; 89:1649-57.

10. Paul D, Löwy I. On objectivity in prenatal genetic care. OBM Genetics 2018; 2:022.
11. Diniz D. The protection of women fundamental rights violated by zika epidemics. Am J Public Health 2016; 106:e9.

12. Valente P. Zika and reproductive rights in Brazil: challenge to the right to health. Am J Public Health 2017; 107:1376-80.

13. Dommergues M, Mandelbrot L, Mahieu-Caputon D, Boudjema N, Durand-Zaleski I; ICI Group-Club de Médecine Foetale. Termination of pregnancy following prenatal diagnosis in France: how severe are the foetal anomalies? Prenat Diagn 2010; 30:531-9.

14. Diniz D. Zika. De sertão nordestinio à ameaça global. Rio de Janeiro: Civilização Brasileira; 2016.

15. Guiland A. Our babies are "little warriors": how love is transforming tragedy in the wake of Brazil's Zika outbreak. The Telegraph 2018; 18 set. https://www.telegraph.co.uk/news/0/ babies-little-warriors-love-transforming-trag edy-wake-brazils/.

16. Dubow S. Ourselves unborn: a history of the fetus in modern America. Oxford: Oxford University Press; 2011.

17. Watson $\mathrm{K}$. The Unacknowledged consensus on abortion. Am J Bioeth 2010; 10:57-9.

Submitted on 28/Sep/2018

Final version resubmitted on 13/Dec/2018

Approved on 21/Dec/2018 